\title{
Trade Unionism in the Cut Flower Industry in Kenya. A Case of Kenya Plantation and Agricultural Workers Union (KPAWU)
}

\author{
Joseph G. Kabiru, (PhD) \\ Lecturer at the Department of Sociology and Social work, \\ University of Nairobi, Kenya
}

Doi: 10.19044/esj.2018.v14n13p215 URL:http://dx.doi.org/10.19044/esj.2018.v14n13p215

\begin{abstract}
Trade unionism in the cut flower industry has been in existence since independence. Immediately after independence, there was an amalgamation of four labour unions which represented workers in different sub-sectors within the agricultural sector. As a result, the representation of workers' labour issues in the agricultural sector was given to only one labour union called Kenya Plantation and Agricultural Workers Union (KPAWU). Since the formation of KPAWU, scholars have enumerated different challenges, both from within and without, that affected the union in fulfilling its mandate to its workers. This article attempts to measure the extent to which the KPAWU has contributed to workers' welfare in the cut flower industry which is one of the sub-sectors in the agricultural sector. Literature review was done on historical development of labour unions in the agricultural sector in Kenya. Further, a comparative survey was used to study workers' welfare in three Kenyan regions which were selected for this study, which are Naivasha, Nanyuki and Thika. Quantitative techniques were used to collect and analyse survey data. These quantitative techniques were supplemented by qualitative data from key informants (KIs) and Focus Group Discussions (FGD). Both univariate and bivariate methods of analysis were used in this study. The article establishes that trade unionism in the cut flower industry in Kenya had experienced several challenges both internal and external, like funding, poor skilled leadership and low membership registration, which have affected its growth. Currently, there is low registration of workers and poor funding of the trade union activities. Therefore, workers in the field were unsatisfied with the union. Thus, this article concludes that there is a correlation between the challenges experienced in the initial establishment of KPAWU and its contribution to workers' welfare.
\end{abstract}


Keywords: Workers' welfare, Trade unionism, Labour relations, Employees, Cut flower industry, KPAWU, Kenya

\section{Introduction}

Trade unionism is the act of organizing groups with the purpose of enhancing the economic, social and political interests of their members in labour relations and sensitizing existing political systems (Schillinger, 2005). Trade unions have several contributions in the society. Fisher (1988) argues that one of the major roles of trade unions is to address the factors that hinder development in the relationships between the owners of capital and workers, such as human rights and unequal relations. Trade unionism can be traced back to the industrial revolution in $17^{\text {th }}$ and $18^{\text {th }}$ centuries in England. In Africa, trade unionism was brought by the colonialists. During inception period, Africans were not allowed to form or join trade unions. Thus, only nonAfrican labourers could start and establish these trade unions. As a result, there was minimal participation of Africans in trade unions due to discrimination by non-Africans. However, with the increased demand for African labour, it became imperative to allow them to form independent trade unions. Accordingly, during the colonial period, there was no apparent difference between the political resistance parties and the trade unions in Africa. These trade unions formed by Africans were adjoined with political parties fighting for independence in the continent. Mboya (1956) denotes that due to a tripartite system that separated Africans, Europeans and Asians, the Europeans desisted from joining the trade unions established by Africans. As a result, the trade unionism in Africa was left to local workers who made them lack synergy of fighting for workers' welfare.

Hence, the rise of trade unionism in Africa was agitated by workers fighting for their rights with the aim of improving their welfare. Kalusopa et al., (2012:2) argued that trade unions in Africa emerged as a response to the despotic capitalist order. The Africans workers had experienced discrimination based on racism where the Europeans workers were given lighter job but with better pay in comparison with their African counterparts. Thus, Africans had to work with low wages even though their assignments were similar to those of non-Africans.

In 1919, the International Labour Organization (ILO) was formed. The constitution of ILO was embodied on the right to freedom of association in the workplace (Budeli, 2012). In 1920 -1921, the African colonies were affected by depression, which led to an intensified struggle for higher wages and better working conditions, especially for African workers. Consequently, the trade unions gained popularity, and the workers' membership in such unions increased. Trade unions in Africa continued fighting for the rights of workers with the sole aim of improving their welfare thus making them more attractive 
(Anyango et. al., 2013). Therefore, it led to numerous strikes in African countries like Ghana, Kenya and South Africa among other countries.

The depression of trade unionism continued in 1922-1929, consequently, leading to the reduction of union activities (Ananaba, 1984). One of the factors which contributed to the decrease of trade unionism in Africa was lack of enlightenment among African workers on their rights. During this period, Africans valued the status they acquired through working in the plantations owned by the white colonialists. Thus, they did not find the need of joining the trade union.

In Kenya, the origin of trade unionism can be traced back to the establishment of colonial rule in the country. During the period, the colonial government introduced the agriculture as the backbone of the country's economy by starting plantation farms called "white highlands". These were fertile lands located in the Kenyan highlands especially in parts of Rift Valley and Central Kenya. The Africans offered cheap labour in those plantations which were owned by the White settlers.

From 1960, trade unionism in Africa was sucked into national politics which was the case in Kenya. Consequently, it was difficult to disassociate the political parties from the trade unions. During this period of struggle for independence, the colonial government tried to discourage trade unions from participating in politics. They viewed many of the industrial disputes as political agitation. On the other hand, the African trade unions perceived the struggle for independence as a national issue which deserved the support of every organized social group. Accordingly, the trade unionism during independence was more aggressive compared to years after independence. According to Willman (2001) report, there are five ingredients of the viability of a trade union which are membership level, union service level, employer recognition, membership participation and employer-provided facilities. These ingredients led to the effectiveness of a trade union before independence.

Kraus (1976) notes that before independence, the Agricultural trade unions in Kenya did not function properly due to interference from the colonial government. The ineffectiveness of trade unions in the Agricultural sector can be attributed to the following three factors. First, the trade unions were economically unnecessary, since the colonial government could negotiate directly with the settlers and were politically difficult to form because of open repression by the colonial settlers and administration (Leitner, 1976). Secondly, there existed infighting among the leaders of these trade unions. These infightings hampered the activities of the trade union. Finally, the government policy on labour in the agricultural sector was biased towards the owners of the plantations who were colonial settlers.

With time, the colonial government failed to tackle social and economic issues in the labour market like the minimum wages for workers. As 
a way forward, the labour unions were allowed to engage the workers in the agricultural sector (Kraus, 1976). This engagement of workers prompted the colonial administrators to allow for collective bargaining spearheaded by the trade union to take place. The organization of trade union in Africa took root only after the establishment of a legal mechanism to legitimize trade unions. In Kenya, the legitimization of the trade union occurred around 1960 (Mindo, 2002). After independence in Kenya, trade unionism changed and separated itself from the political parties. The aim was tames trade unions from consolidating people's power thus turning against the newly independent African state leaders (Budeli, 2012).

The existing industrial trade union system in the agricultural sector in Kenya was established in 1952. The first agricultural labour unions to be formed were the 'Sisal Plantations Workers Union and Coffee Plantations Workers Union' in 1959, followed by the 'Tea Plantation Workers Union and General Agricultural Workers Union in 1960 (Kraus, 1976:43). The four trade unions in the agricultural sector were merged in 1963 to form Kenya Plantation and Agricultural Workers Union (KPAWU). This union was started in Nairobi but later spread to Rift Valley and Nyanza Provinces. In 1972 -1973, KPAWU had not influenced the working environment of the workers. This was as a consequence of leadership squabbles in the union, dispersed population especially in the rural areas, illiteracy of the workers in the farms and inaccessibility of workers by trade unionists in their place of work.

According to Kraus (1976) and Beyene (2014), trade unions in Africa were ineffective in dealing with member's' labour issues. This had led to a negative perception amongst members of the union who perceived that trade unions had little consciousness on their interests. Also, the formation of KPAWU was marred by tribalism and factionalism which threatened its survival. Tribalism in KPAWU had adverse effects on its effectiveness. This is in spite of Muir \& Brown's (1974) argument that the trade union can have a positive impact as they assist in the formation of a stable and productive labour force. One of the positive impacts on workers' welfare was high wages bargained by the trade unions which was even higher than government legislated minimum wages for low cadre workers in the cut flower industry as denoted by Dolan (2005).

In the cut flower industry in Kenya, which was the scope of this study, the KPAWU aimed to improve the working environment of its members. This aim was achieved by improving the working conditions of its members, fighting for better wages, protection of employees from unfair labour practices, education of workers on their rights, influencing government decisions on matters affecting the workers and taking legal actions against unfair labour practices (Ogolla, 2015:50). However, Riisgaard and Gibbon (2014), reported 
that the promotion of labour rights and protection of workers' welfare through the trade union in the cut flower industry has been wanting.

According to Kalusopa, et. al., (2012), the prominent services provided by the trade union movement in Kenya include workers training and collective bargaining. The training among the members of the trade union helps in building their capacity and sensitizes them on their rights. It also gives them insights into issues related to their union and enables workers to master the tools of change through participation. Further, the training boosts membership recruitment and sensitizes members on the challenges experienced in the cut flower industry. Some of the areas of training emphasized by KPAWU include working condition issues like salary and wages, retrenchment, HIV/AIDS among other emerging labour related challenges which affect both members and their union. Further, it focuses on the economic aspects of its members realized through Collective bargaining agreement (CBA) negotiations.

According to Odhong and Omolo (2014), the cut flower industry has experienced a reduction in registered workers in the trade union (KPAWU). Among the reasons which have contributed to low trade unionism drive was first, union failure in training its members to boost trade union membership recruitment. Second, lack of the intervention process by the union on behalf of workers in the cut flower industry. In addition, workers in the industry have failed to work closely with labour unions in fear of dismissal. This study, in line with Miller (2012) established instances where the management of the cut flower farm threatens workers with job losses to deter them from joining unions. In a peculiar situation, some workers in the cut flower farms have not seen the benefits of joining the labour union (KHRC, 2012). In spite of this, Fashoyin (2010) reported that the trade union had exerted pressure in fighting for the rights of the workers. According to Perry (2012), one of the reasons why the workers register with the labour union is to ensure the protection of their rights.

The wages paid to workers in the cut flower industry has been criticized as being extremely low. As a result, it is not commensurate with the labour power offered by the workers (KHRC, 2012). Mlynska et al., (2015) denote that workers in the cut flower industry have continued to earn meagre monthly wages. However, on the other side, the cut flower farms have justified low wage given to workers as the only way in which they can be profitable. This is contrary to Kraus (1976) who reported that union activities had contributed to increase in workers' wages among other benefits.

\section{Methodology}

For this article, comparative survey research design was employed to measure the cut flower workers' profile, working condition and remuneration characteristics in the study area. According to Singleton et. al., (1988) survey 
research is done in a scenario where a large number of respondents are selected through probability procedures. A comparative survey research design is used while measuring variations between two or more groups in one variable. Accordingly, Bryman (2008), comparative survey design is useful when the study is out to examine particular issues or phenomena in two or more geographical locations with the intention of comparing manifestations in different socio-cultural settings using the same research tools.

This study was carried out in Kenya which has a population of 38.6 million; with a majority being young people aged 15 and 30 years (RoK, 2017). Three cut flower regions namely, Naivasha, Thika and Nanyuki were purposively selected. Naivasha is the hub of cut flower industry in Kenya. Thika region was selected to control geographical diversity. Finally, Nanyuki region was selected due to its rural socio-economic characteristics. The cut flower farms in the three regions were selected based on the regions' socioeconomic characteristics. Consequently, from the three selected regions, a total of thirteen cut flower growing farms were selected as follows: Naivasha (7), Thika (4) and Nanyuki region (2). Proportionate sampling was used to select a total of 358 workers from the three selected cut flower regions. In total, 196 workers were sampled from Naivasha, 108 workers from Thika and 54 workers from Nanyuki.

In this study, two options were adopted to collect the data from the sampled cut flower workers. The basis of sampling the workers was whether or not the management allowed the research team to access workers in their natural environment during the time of interviews. In the first option, the research team were allowed to access the workers in their working station. Simple random sampling method was used to sample workers for interviews in one farm. The second option was snowball sampling method, employed to select workers in twelve cut flower farms, where the management of the farms denied the research team direct access to the farm or workers felt threatened of being interviewed within or near their places of work.

In this study, a standardized questionnaire was used to collect primary data from the sampled respondents through face to face interviews. Quantitative data was supplemented with qualitative data collected from the key informants and in Focus Group Discussions. Qualitative data was collected from the key informants and the members of the three Focus Group discussions. In this study, eighteen key informants were purposively selected from the three selected regions as illustrated in Table 1. 
Table 1: Summary of Key Informants Selected for the Study

\begin{tabular}{|l|l|l|l|l|l|}
\hline $\begin{array}{l}\text { Organization } \\
\text { / Place }\end{array}$ & Naivasha & Thika & Nanyuki & $\begin{array}{l}\text { Type of data } \\
\text { collected }\end{array}$ & Total \\
\hline $\begin{array}{l}\text { Focus Group } \\
\text { Discussion }\end{array}$ & $\begin{array}{l}\text { One FGD } \\
\text { with 8 } \\
\text { participants }\end{array}$ & $\begin{array}{l}\text { One FGD } \\
\text { with 8 } \\
\text { participants }\end{array}$ & $\begin{array}{l}\text { One FGD } \\
\text { with 8 } \\
\text { participants }\end{array}$ & $\begin{array}{l}\text { Primary data } \\
\text { (Qualitative) }\end{array}$ & $\begin{array}{l}\text { Three } \\
\text { FGDs } \\
\text { comprising } \\
\text { of 24 } \\
\text { participants }\end{array}$ \\
\hline $\begin{array}{l}\text { Human } \\
\text { resource } \\
\text { managers } \\
\text { from Cut } \\
\text { flower farms }\end{array}$ & 5 & 3 & 2 & $\begin{array}{l}\text { Primary data } \\
\text { (Qualitative) }\end{array}$ & 10 \\
\hline $\begin{array}{l}\text { Labour union } \\
\text { officials } \\
\text { (KPAWU) }\end{array}$ & 1 & 1 & 1 & $\begin{array}{l}\text { Primary data } \\
\text { (Qualitative) }\end{array}$ & 3 \\
\hline $\begin{array}{l}\text { Ministry of } \\
\text { labour } \\
\text { official/s }\end{array}$ & 2 & 1 & 1 & $\begin{array}{l}\text { Primary data } \\
\text { (Qualitative) }\end{array}$ & 4 \\
\hline $\begin{array}{l}\text { Kenya } \\
\text { Flower } \\
\text { Council }\end{array}$ & The chairperson & $\mathbf{4}$ & $\begin{array}{l}\text { Primary data } \\
\text { (Qualitative) }\end{array}$ & 1 \\
\hline $\begin{array}{l}\text { Total } \\
\text { data } \\
\text { (Qualitative) }\end{array}$ & \\
\hline
\end{tabular}

The selection of members of FGD and KIs was based on their experience and expertise in the working environment of the employees in the cut flower industry in Kenya. The three FGD and eighteen KIs were conducted using interview guides.

\section{Discussion}

In this study it was established that the trade union mandated with protection and improvement of workers' welfare in the cut flower industry is the Kenya Plantation and Agricultural Workers Union (KPAWU). This study established that the membership level in KPAWU of workers in the cut flower industry was above half at $53.4 \%$. This was deviates from previous studies (Gårdman, 2009; Leipold and Morgante, 2013; Odhong and Omolo, 2014) which had reported low membership in the trade union. Willman (2001) illustrates that the influence of a trade union depends on its success in raising membership. However, this percentage was still low. During the FGD held in Nanyuki, one participant reported that:

There were several reasons which were highlighted as the cause of low membership to a trade union. One of the reasons was that the KPAWU was not aggressive in sensitising its members. As a result, some workers were not aware of the 
process of joining the union. Second, some workers were not interested in joining the trade union due to its lack of efficiency in dealing with issues raised by its members. Third, the seasonality status of the employees working in the cut flower farms where their services are mostly required during the peak period. Thus, after the end of the peak season which starts from November- May the workers in the contract are laid off. Fourth, some workers felt that the trade union was already compromised by the management of the cut flower farms. Finally, threats and intimidation issued to workers by the management of the farms discouraged them from joining the union. Workers were threatened with summary dismissal by the management when they had joined the trade union.

Poor service was another factor that affected trade unionism among the workers in the cut flower industry. The workers were asked whether or not the trade union officials had visited them at their place of work. Majority of workers $(63 \%)$ had seen the trade union officials visiting their farms. In exit, voice and loyalty theory one of the roles played by the trade union is taking the voice option on behalf of the workers. The voice option is achieved when the trade union negotiates or voices the worker's grievances to the management which was not the case in this study. Thus, visitation by union officials raised different expectations among the workers. Some of these expectations reported during the FGD include: sensitizing and registering them to become members of the union, intervening on their behalf to the management and protecting their rights. Further, the FGD participants also expressed concerns about grievances that were yet to be resolved.

This study wanted to establish whether workers in the cut flower industry were allowed to join trade unions freely. A majority of workers (66\%) were allowed to join the trade union freely. Thus, at least a third of the workers were yet to enjoy the freedom of expression.

The study was to establish the benefits enjoined to workers after joining a trade union (KPAWU) in the cut flower industry. Workers were asked to list the benefits accruing from joining a trade union in order of priority. In this study, $48 \%$ of workers reported that trade union negotiates on their behalf on Collective Bargaining Agreement (CBA). 33\% of the workers did not see the benefits emanating from being a member of a trade union as it was dormant. Thus, even though the trade union has been in existence since independence, its impact was yet to be felt by at least a third of the workers in the industry.

This study endeavoured to find out whether or not the KPAWU was fighting for the rights of the workers. Most of the workers (68\%) reported that trade unions fight for their rights. However, there are still other workers in the 
industry whose rights are breached. These employees work in non-unionized farms or are seasonal employees working on a rotational basis as revealed during FGD in Thika region.

This study attempted to establish whether the trade union activities responded to workers' needs. The variable was measured by asking the workers whether trade union's activities in the cut flower industry responded directly to their labour needs. Almost $69 \%$ of workers reported that trade union activities responded to their needs against $28 \%$ who felt otherwise. Further, this study revealed that a majority of workers (44\%) perceived that the union acted on behalf of workers in addressing their grievances on working environment. However, $31.4 \%$ of workers reported that the trade union has never acted on their behalf. Thus, almost a third of workers in the cut flower industry observed that the trade union was playing its role.

This study sought to find out whether the trade union in the cut flower industry organizes employees' training on various labour related laws and regulations geared towards the improvement of their working environment. $60 \%$ of the workers reported that the trade union offered training while $31 \%$ disagreed. This shows that to great extent workers in the cut flower industry were sensitized by their union through various trainings. However, a third of the workers reported that such trainings were yet to be offered in their working environment. According to a report by a key informant from Nanyuki, the trade union had limited funds, thus unable to train all the workers in the cut flower farms especially those farms, located in the rural areas which were inaccessible. Further, a majority of workers trained by the trade union on labour related issues were the shop stewards. Finally, according to FGD in Naivasha region, some cut flower farms were not unionized which has affected the training process by the union.

The study sought to find out whether the trade unions' officials were active in their place of work by regularly visiting them. Visitation was operationalized to mean listening to workers grievances and concerns and exploring ways resolving these labour related concerns with the management. Most of the workers (63\%) in the survey reported that the trade union officials visited their farms. The study further, measured whether there was variation in visitation by trade union's officials in Nanyuki, Thika and Naivasha. In Thika region, most workers (72\%) reported that the trade union officials visited them while Naivasha and Nanyuki regions had 62\% and 50\% respectively. Thus, in general, the trade union in Thika was probably more active than in other two regions, followed by Naivasha.

When workers were asked to state how trade union can help to improve their welfare, a majority (59\%) reported that they should fight for their rights. $18 \%$ of the workers observed that the labour union should negotiate for the favourable working environment regarding fair minimum wages and better 
working environment. Finally, others workers (12\% and $11 \%)$ felt that labour unions should sensitize workers on their labour rights and help them to join the labour unions.

The following were some of the weaknesses listed by the workers which faced KPAWU as a labour union in charge of workers in the cut flower industry. First, some union officials were not effective in industrial relations and as a result; they lacked interpersonal social skills while dealing with workers as well as the management of cut flower farms. Second, the labour union had forgotten sensitizing its members on their rights. Third, some workers reported that they only encountered the labour union when there was an issue between the workers and the employer, like a strike or when the union officials were collecting their agency fees from the farm.

During FGD it was reported that the process of agency fee deductions begins when management is approached by the trade union to submit names of workers who qualify as members of a trade union to revise their terms and conditions based on prevailing collective bargaining agreement between the trade union and the employer. Agency fees are paid to a trade union that has a registered recognition agreement with an employer in the industrial court. The employer is bound by the collective agreement to deduct agency fees from the wages of workers who qualify as members of a trade union. This study attempted to measure the impact of the trade union on workers welfare. The results were that the unit increase of the effectiveness of the trade union decreases the probability of higher workers' welfare $(-9.6 \%)$. Thus, joining trade union inversely affected the expenditure of the cut flower workers due to deduction of the agency fee by the employer on behalf of the trade union.

The challenges experienced by the labour union while expediting their political role in the cut flower farms in Kenya were as follows. First, some of the cut flower farms denied access of the workers by the trade union officials. Secondly, the management of some cut flower farms discouraged their workers from joining a labour union. Discouragement of workers' took the form of intimidation and threats of being sacked by their respective farms. Third, some farms failed to respond to the letters from unions requesting for workers sensitization on their rights. Nonresponse to the letters from unions has led to a delay in empowering workers on issues related to their rights. Finally, the union lacked funds to carry out their mandate in the cut flower farms.

\section{Conclusion}

Trade unionism in the agricultural sector in Kenya faced several challenges while addressing labour issues from its initial establishment. Among the challenges faced by KPAWU since its inception are tribalism, leadership squabbles, low registration among workers and negative politics 
from the owners of the capital. Other challenges were lack of training of its members and lack of accessing the workers in their place of work which hampered workers' registration. This has affected the funding of the KPAWU due to reduced agency fees collected from the low number of the registered members, thus affecting its mandate on protecting their welfare. Consequently, the union has failed in satisfactorily addressing the labour issues of the workers in the cut flower industry. As a result, at least a third of workers did not see the benefits of being members of a trade union, attributed to the fact that KPAWU does not adequately implement its mandate. Currently, the same challenges which affected KPAWU at inception continue to thrive thus, affecting the workers' welfare in the cut flower industry.

\section{ACKNOWLEDGEMENT}

This work has been extracted from my PhD thesis entitled: The social structure of cut flower industry: A comparative survey of workers' welfare in Kenya. The study was done by Joseph Githui Kabiru, Department of Sociology and Social Work, University of Nairobi. I appreciate the support from Professor Paul N. Mbatia and Professor Edward K. Mburugu during the research for the study and also their guidance in writing this article as coauthors.

\section{References:}

1. Ananaba, W. (1979). The trade union movement in Africa: Promise and performance. London: Hurst \& Company.

2. Anyango, C., Obange, N., Abeka, E., Ondiek, G. O., Odera, O., \& Ayugi, M. E. (2013). "Factors affecting performance of Trade Unions in Kenya." American Journal of Business and Management, 2(2), 181185.

3. Beyene, T (2014) Socio-Economic Opportunities and Implications of Cut flower Industries in Ethiopia: The Case of Flower Farms in the Rift Valley and Sebeta. Master Thesis 2014. Department for International Environment and Development Studies, Noragric

4. Bryman A. (2008). Social Research Methods. London: Sage Publications Ltd.

5. Budeli, M. (2012). Trade unionism and politics in Africa: the South African experience. Comparative and International Law Journal of Southern Africa, 45(3), 454-481

6. Dolan, C. (2005) "Fields of Obligation: Rooting ethical sourcing in Kenyan horticulture." Journal of Consumer Culture Vol. 5(3) 5.

7. Fashoyin, T. (2010). Collective Bargaining and Employment Relations in Kenya. Working Paper No. 13. Geneva: International Labour Office. 
8. Fisher, J. (1998). Non-governments: NGOs and the political development of the Third World. Hartford: Kumarian Press, Inc.

9. Gårdman, K. (2008) "Fairtrade and Human Rights in the Kenyan Cut Flower Industry." Lund's University.

10. Kalusopa, T., Otoo, K., \& Shindondola-Mote, H. (Eds.). (2012). Trade Union Services and Benefits in Africa. African Labour Research Network [ALRN].

11. Kenya Human Rights Commission (KHRC). (2012). Wilting in Bloom: The Irony of Women Labour Rights in the Cut Flower Sector in Kenya. Nairobi: KHRC.

12. Kraus, J. (1976). African trade unions: Progress or poverty? African studies review, 19(3), 95-108.

13. Leipold, B. \& Morgante, F. (2013). "The Impact of the Flower Industry on Kenya's Sustainable Development.” IPPR 2012/2013. International Public Policy Review.7 (2).

14. Leitner, K. (1976). The situation of agricultural workers in Kenya. Review of African Political Economy, 3(6), 34-50.

15. Mboya, T. (1956). Kenyan Trade Unions Fight for Freedom. Africa Today, 3(2), 2-5.

16. Miller, C. (2012). "Fresh Cut Flowers and Exploitation.” Perspectives on Global Development and Technology, 11(1), 88-98.

17. Mindo, J. (2002). The role and challenges of Kenyan trade unions in the context of macroeconomic reforms. MA Project (Published). University of Nairobi.

18. Mlynska, A.; Wass, G. \& Amoding F. (2015). "Thorns amongst the roses. A cross-country analysis of human rights issues." IPIS Publication.

19. Muir, J., \& Brown, J. (1974). Trade Union Power and the Process of Economic Development: The Kenyan Example. Relations industrielles/Industrial Relations, 29(3), 474-496.

20. Odhong', A. \& Omolo, J. (2014). "An analysis of the factors affecting employee relations in the flower industry in Kenya: A case of Waridi Ltd, Athi River.' International Journal of Business and Social Science. 5(11), 147-160.

21. Ogolla, W (2015) Effects of economic liberalization on trade unions: A case study of the Kenya Plantation and Agricultural Workers Union, 1980-1998. MA thesis. University of Nairobi.

22. Perry, B. (2012). "The structure and dynamics of cut flower export markets from Kenya and Ethiopia, with particular reference to trade to Norway." Nupi Working Paper, 997, 1-26.

23. Republic of Kenya (RoK). (2017). Economic Survey 2017. Kenya National Bureau of Statistics. Nairobi: Government Printer. 
24. Schillinger, H. (2005). Trade unions in Africa: Weak but feared. International Development Cooperation: Friedrich Ebert Stiftung. Occasional Papers 2005(2).

25. Singleton, A. (Jr.); Strait, C.; Strait, M. \& McAllister, R. (1988). Approaches to social research. New York: Oxford University Press.

26. Willman, P. (2001). The viability of trade union organization: a bargaining unit analysis. British Journal of Industrial Relations, 39(1), 97-117. 